\title{
En Stenalders Gravplads ved Harreby.
}

\section{Af Therkel Mathiassen.}

Lidt syd for Harreby i Hygum Sogn ligger et af Sønderjyllands mærkeligste Oldtidsminder, en Stenalders Gravplads. Ifojt og smukt ligger den, paa sydvestskraaningen af et Bakkelrag, med vid Udsigt, dels mod syd over de lave Heder og Plantager langs Gram Aa og Gelsaa, dels mod de lave Strakninger i Vest, hvor Ribe Domkirke rager op som et Vidne om, at vi er i en ældganmel Kulturegll. Naar man kommer fra Harreby ad V'ejen syclpaa, skal man 6 --700 $\mathrm{m}$ ind over Marken mod Vest, lige før man naar den stejle Bakke ned mod Lasl,jerggaard, for at fincle Gravplaidsen; den tilhører Enkefru Hansine Ebbesen, Harreby, men Arealet, hvorpaa den ligger, er Jortforpagtet til hendes Svigersøn, Gaardejer Johannes Poulsen, Lasbjerggaard.

Efter at der ved Plojning var fundet et lille Stenkammer paa Marken her, foretog daværende Museumsdirektør C. M. I.und, Haderslev, i 1934 en Under'sogelse af Pla.lsen, hvorved lian afdakkede to smaa Dyssekamre (Planens Nr. 1 og 2), en anden stensat Grav (Nr. 3), hvori der fandtes to Lerkar, og nogle Stendynger; Sagerne fra Lunds L'ndersogelse findes i Haderslev Amts Museum, hvis nuværende Leder, cand. mag. Hans Neumann, velvilligt har stillet Materialet derfra til min Raadighed. I 1936 og 1938 fortsatte Nationalmuseet med Forfatteren som Leder Udgravningerne ved Harrebr; hvorved der afdækkedes et større Areal og fandtes flere Mindesmerker, navnlig et fuldstændig urørt Dyssekammer (Grav 5). Undersøgelsen afsluttecies med, at et Areal af Gravpladsen, $25 \mathrm{~m}$ langt og $18 \mathrm{~m}$ bredt, omfattende de vigtigste og bedst bevarede af Gravene, ved Ejerindens og Forpagterens Velvilje blev fred!yst. For dette og for dien store Hjælp under Udgravningen, der blev ydet af Ejerindens Søn og Svigersøn, Gaardbestyrer Johannes Ebbesen, og Ciaardejer Johannes Poulsen, maa jeg bringe Museets bedste 
Tak; de ses begge paa Billedet Fig. 1, hvor Johannes Poulsell ined Stensøger leder efter flere Kamre.

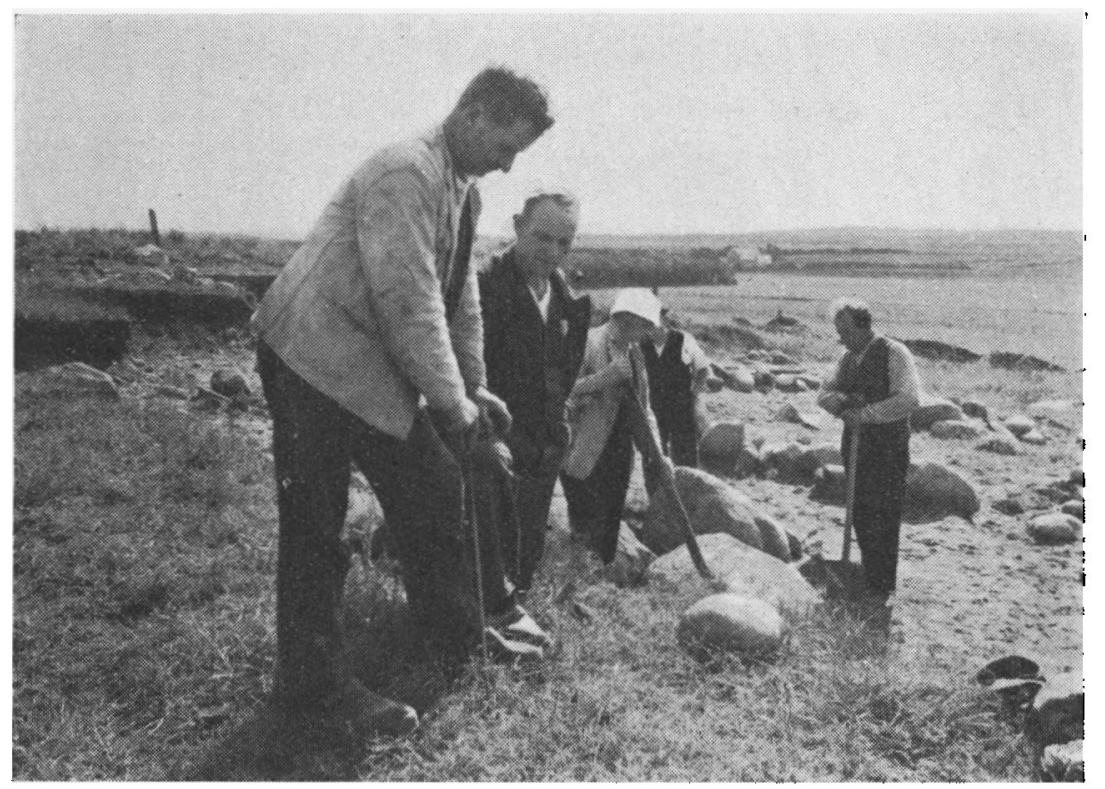

Fig. J. Der ledes med Stensøger efter nye Kamre.

Th. Andresen tot.

Harreby-Gravpladsen er gentagne Gange navut i den ark: ologiske Litteratur $\left.{ }^{1}\right)$; men endnu or den ikke blevet rigtig beskrevet.

Gravpladsen ligger under flad Mark paa Terræn, der skraaner svagt mod syd og Vest. Faldet er paa det fredede Areal

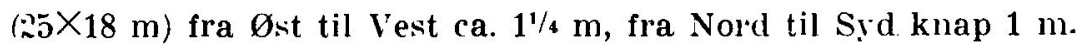
Højden over Havet ligger omkring $25 \mathrm{~m}$; mod Nordøst fortsatter Stigningen til Bakkens Top, der ligger c. $31 \mathrm{~m}$. o. H.; mod syil cg Vest falder Terrænet ret stejlt mod den flade, sandede Slette, hvori Aaløbene har skaaret sig ned. Jordbunden er Morænegrus med 'mange Sten i Undergrunden. Der var ikke for Under-

1) Brondsted: Dammarks Oldtid I, s. 1992000 og 352 . Acta Archaeologica 19:3\%, S. 324-25. Schwantes: Vorgeschichte Schleswig-Holsteins, $\therefore$ 200, Fig. 218. A berg: Kulturmotsättningar i Danmarks Stenålder. s. $20 \mathrm{og} 2 \mathrm{X}, \mathrm{H}$. Neumann: Nogle nedgravele Stenkambe fra Hadersler Amt. Fra Ianmarks I'ngtid, S. (ii3. 


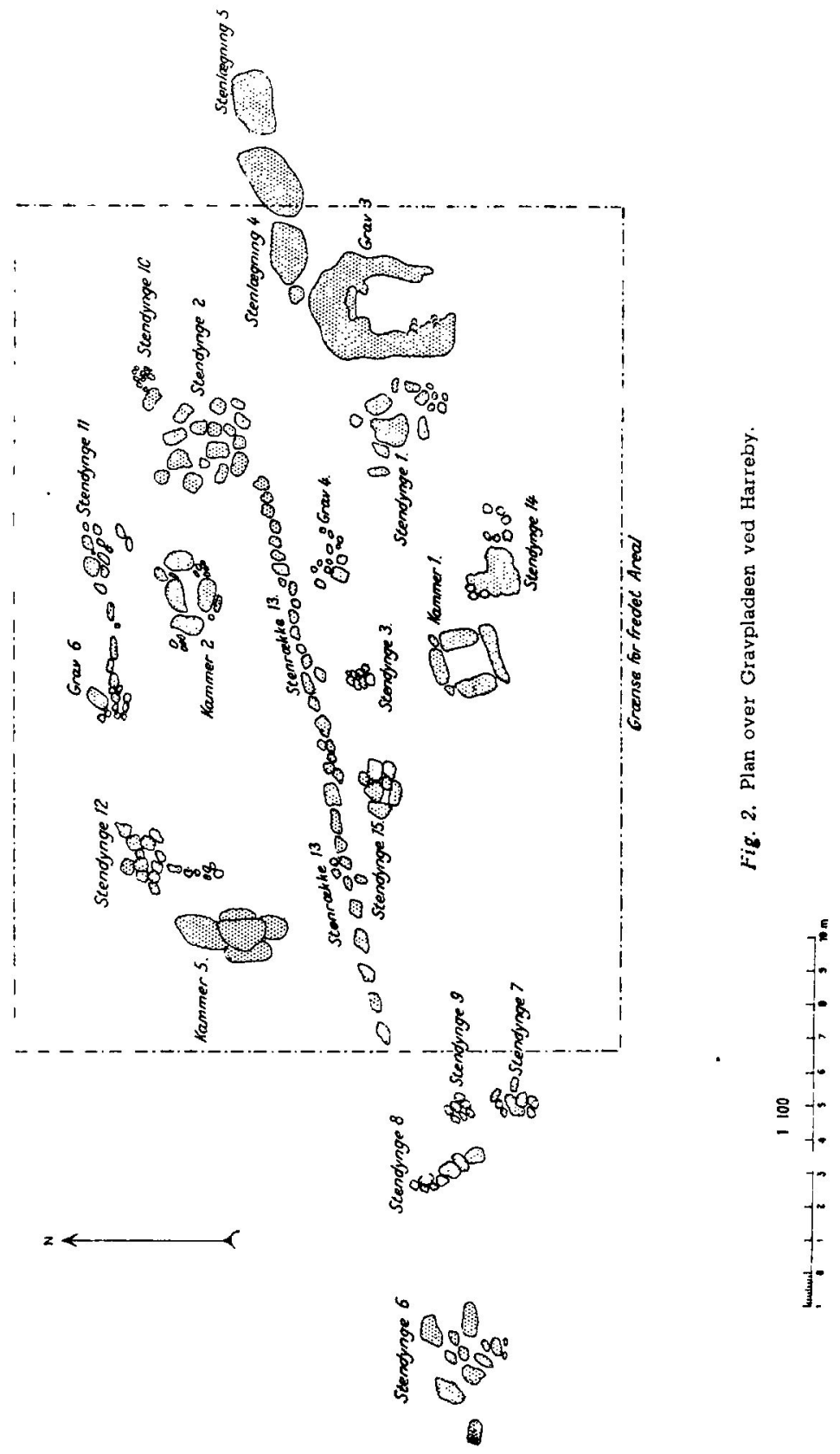


søgelsen nogetsomhelst Tegn til, at der paa Stedet har været nogen Høj; alle Gravene maa have været gravet ned i Jor(len; Terrænets Fald er saa svagt, at der næppe kan være Tale om, at den Jord, der dækkede Kamrene, kan vare flyttet eller skyl-

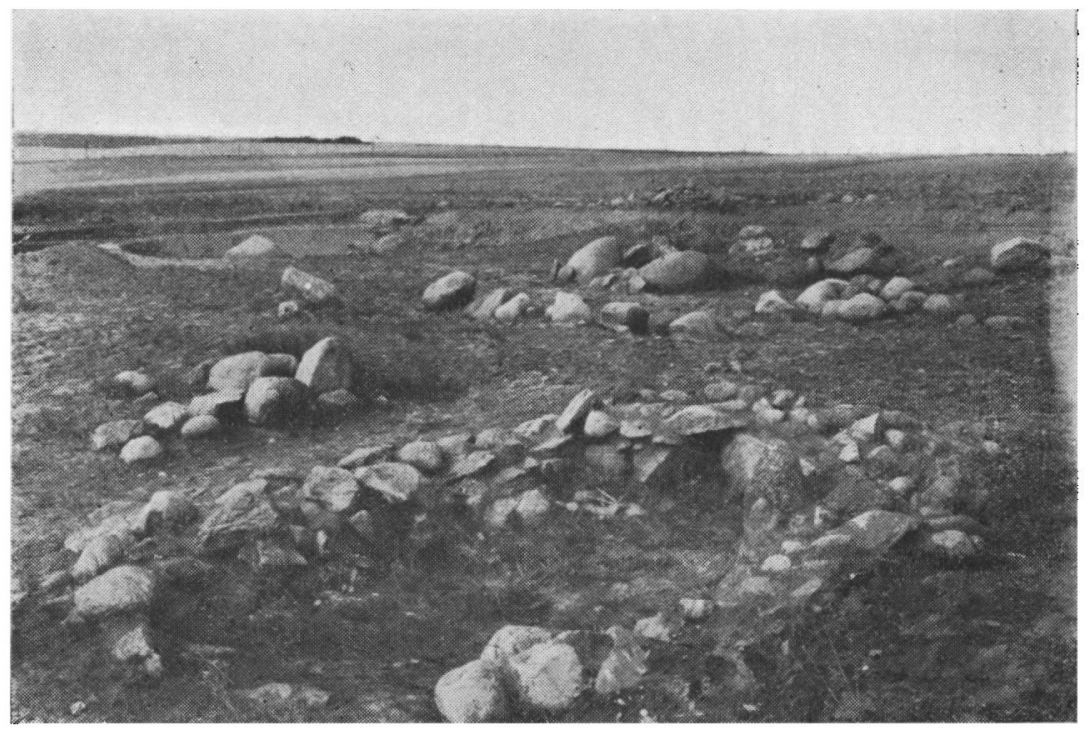

Fig. 3. Gravpladsen, set tra Øst; i Forgrunden Grav 3.

T. M. fot.

let ned fra et højereliggende Terræn, saa meget desto mere, som et gammelt nord-sydgaaende Markskel lige Øst for Gravpladsen i hvert Fald i de senere Aartier maa have forhindret al Jordflytning.

Planen Fig. 2 giver en Oversigt over hele Gravpladsen; der er dels nogle helt eller delvis bevarede Grave og dels et Antal Stendynger, hvoraf i hvert Fald nogle er fonstyrrede Grave, Stenlægninger og Stenrækker. Fig. 3 giver en Oversigt over Pladsen, set fra Øst.

K a m m e 1 (Fig. 4) er et lille aflangt-firkantet Drssekammer, bygget af 4 stærkt indadskraanende Baresten, der omslutter et Gravrum, der i Bunden er 2,6 m langt og $1 \mathrm{~m}$ bredt; Bærestenenes Højde er 0,80-0,90 m. Det var dette Kammer, der gav Anledning til, at hele Gravpladsen blev opdaget, idet Plo- 
ven stødte paa en flad Dæksten, der laa over det; denne Sten blev fjernet, og dermed blev det opdaget, at der var et Kammer derunder; omkring det laa en Stenpakning. Ved Undersøgelsen fandtes et Brudstykke af en Flintdolk og et lille uornamenteret Lerkarskaar.

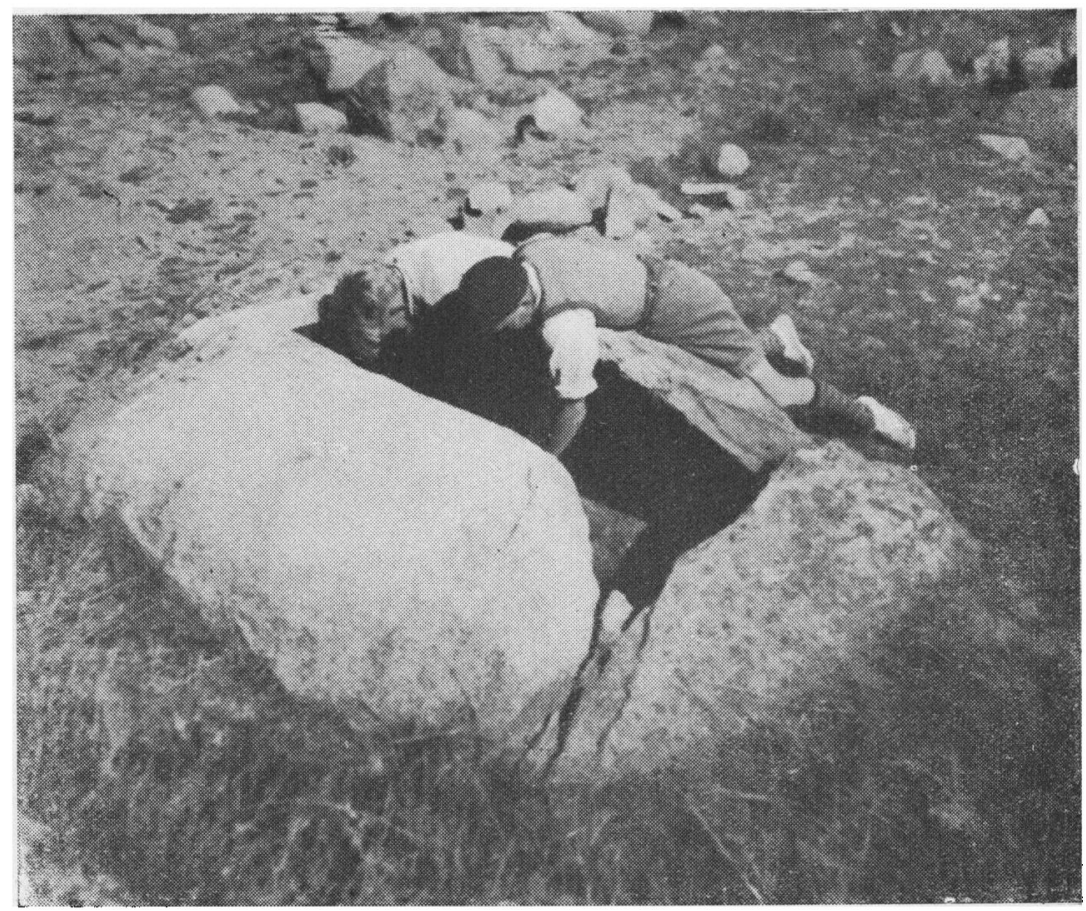

Fig. 4. Kammer Nr. 1.

Th. Andresen fot

$\mathrm{K}$ a $\mathrm{m} \mathrm{m}$ e $\mathrm{r} 2$ ligner meget det første, som dette bygget af 4 Bæresten, der omslutter et Gravrum, $1,65 \mathrm{~m}$ langt og $0,70 \mathrm{~m}$ bredt, 0,80-0,90 $\mathrm{m}$ højt; men her er det kun Endestenene, der hælder indad, Sidestenene staar lodret. Heller ikke her er Dækstenen bevaret; den er rimeligvis tidligere taget af Ploven. Der fandtes ingen Oldsager i dette Kammer.

Gra v 3 er en stærkt ødelagt kistelignende Grav, der har været omgivet af en ret svær Stenpakning, der er bevaret paa Nord- og Vestsiden (Fig. 5; ses ogsaa i Forgrunden paa Fig. 3). 
Af selve Kistens Sten er kun een bevaret, i Nordenden; en ret flad, 0,35 $\mathrm{m}$ høj Sten; men at der har været lignende Sten i hvert Fald langs Vestsiden, ses af de Pakninger af smaa Stenfliser, der har udfyldt Mellemrummene mellem dem og som endnu findes; Graven er anlagt paa den oprindelige Undergrund og synes at have været ca. $2^{1 / 2} \mathrm{~m}$ lang og $1 \mathrm{~m}$ bred.

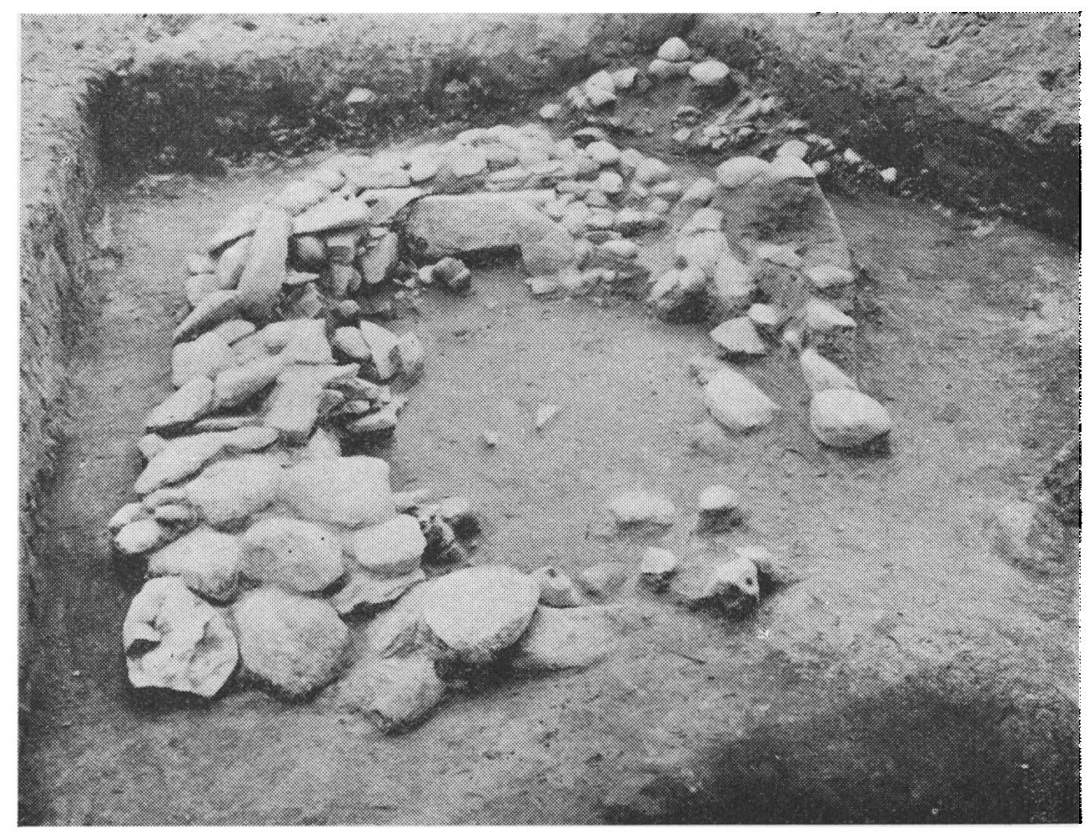

Fig. 5 Grav 3: Lerkarrene ses i Hjørnet.

C. M. Lund fot,

I Gravens Nordvesthjørne fandtes to Lerkar, der endnu ses liggende paa deres oprindelige Plads paa Fig. 5. Det ene, Fig. 6, er et smukt Kar af den Form, der kaldes Tragtbæger, med en rund Bug og en opadtil udvidet Halvdel; paa Overgangen mellem Bug og Hals findes 4 smaa Hanke. Overfladen er dækket med Ornamenter, der paa Bugen er lodret, paa Halsen vandret ordnet, dels kraftige Zigzagbaand, dels parallele Linjer, udført i den Teknik, der kaldes Furestik: Pinden anbringer Stik ved Stik ganske tæet, saa der dannes en ujævn Rille, der paa Afstand ligner det Ornament, man faar ved at trykke en Snor 
lied i det vaade Ler. Det andet Kar er ogsaa et Tragtbreger, men minclre og uden Ornamenter; desuden fandtes i Graven en Ravpelle og et Lerkar, drkket af bueformede stempelindtryk ( Fig. 9, 7).

(i r a v 4 symes at vare Resterue af en Grav med Ramme af milllle Sten men lielt ollelagt, saa hrerken Form eller Sturrelse nu kan ses; ved Lndersigelsen fandtes nogle snaa Skaar med Snoreornamentik.

li a m m e j er et Dyssekammer, bestaaende af 1 Baresten og en Dxksten (Fig. 7-9). Bxyrestenene er store, svære, ret uregelmassigt formede Sten, de tre med Flader, der skiaaner ret strerkt indad mod Graviumnet;

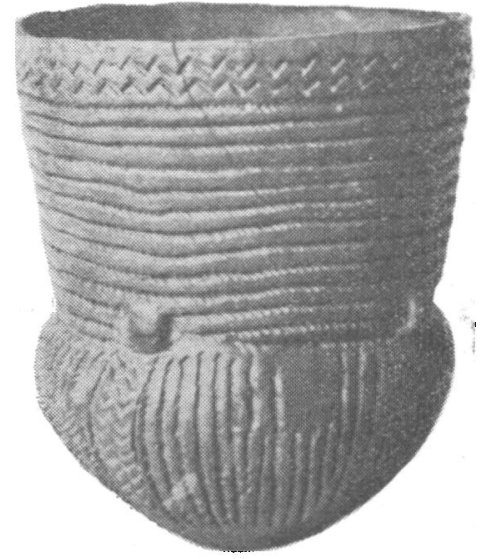

Fig. 6. Lerkar tra Grav 3.

Omtr. trediedel Storrelse. Efter Brondsted. len østlige Bæresten er mindre og mere flad og var allerede $\mathrm{i}$ Oldtiden væltet ind i Kannleret, og Mellemrummene mellem den og Dækstenen var da udfyldt med flere mindre, flade Sten. Dækstenen er en stor, klumpet, uregelmæssig-trekantet Sten, der paa Grund af den valtede Bæresten indtog en ret skraa Stilling. Omkring Kammeret var der, som det ses paa Fig. 7, en Pakning af mindre Sten, ligesom alle Aabninger ind til Gravrummet var fyldt med mindre Sten. Der var ikke Tvivl om, at demne Dysse henlaa fuldstændig uforstyrret siden Oldtiden. Ejendommeligt var det, at den laa saa dỵbt, idet Dækstenens Top laa $0,30 \mathrm{~m}$ under den oprindelige Markoverflade og Bunden af den Udgravning, hvori den laa, 2,0 m under Markoverfladen. Demme Udgravining var af meget betydelige Dimensioner, i Nord-Syd $14 \mathrm{~m}$, i Øst-Vest $6 \mathrm{~m}$ i Tværmaal, og fyldt med Jord, der var stærkt blandet med Mula.

Det var med en vis Spænding, at vi gik i Gang med Lnder- 
sogelsen af dette Dyssekammer; det er forholdsvis faa urorte Dyssekamre, der har været Lejlighed til at undersoge, fordi de fleste Dysser ligger frit og altfor let tilgængelige; men her havde den jo ligget godt gemt, beskyttet af Jorden. Først blev de lose Paksten fjærnet; men at komme ind i Kammeret viste sig ikke

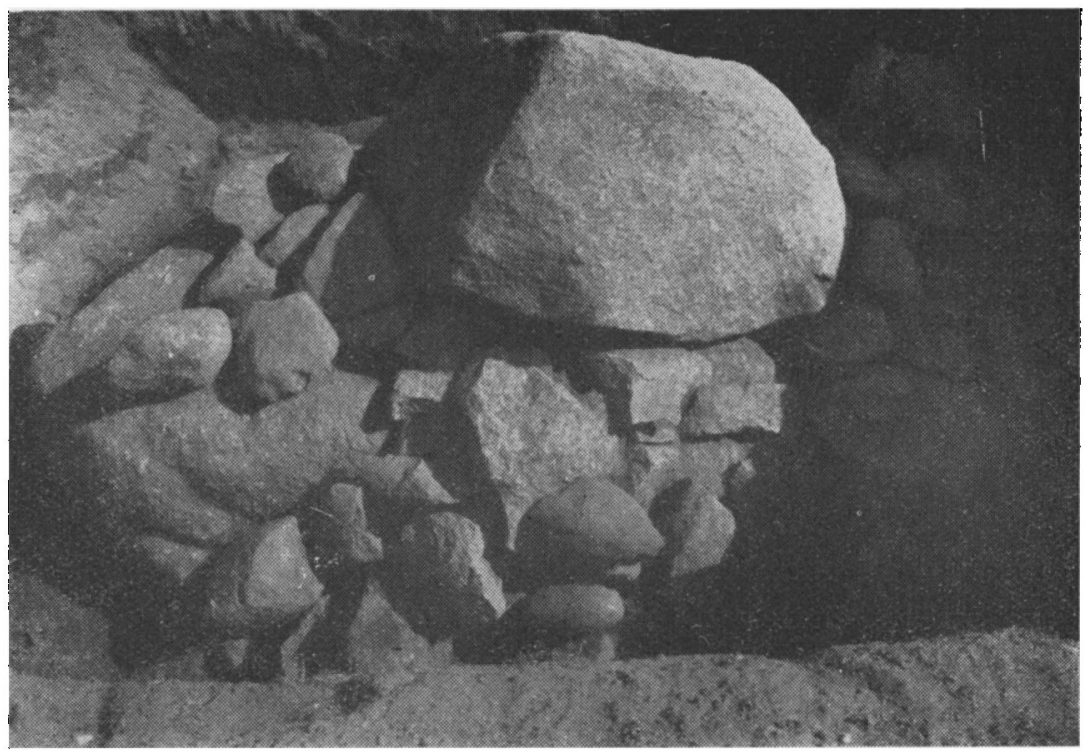

Fig. 7. Kammar 5 med sin Stenpakning, set fra Vest.

T. M. fot.

let. Det lykkedes dog ved Hjælp af to laante Dunkrafte at lofte Iækstenen saa meget, at det var muligt at kravle ind i Kammeret fra Østsiden, efter at de mindre Sten over den væltede Bacresten var fjernet. Udgravningen af det aflangt-firkanterle Kanmer blev dog en skuffelse; der var intet andet deri enct grovt, muldblandet Sand, hvori laa enkelte smaa Trakulstumper og et Par smaa Stykker ildskarnet. Flint; Skeletresterne har njensynlig ikke kumnet hevares i den kalkfattige Jord, og eventuelle Gravgaver maa have været af et forgængeligt Stof.

Efter at Kammeret var tomt, blev den valterle Barester rejst op ved Hjælp af Dunkraft; men da Dækstenen blev lagt ued paa den, skred den vestlige Baresten og væltede ind i det 
tomme Kammer. Ved Hjælp af en Talje, laant fra Gram Skove, blev nu Drkstenen loftet hen paa Nordenden af derr nordlige Bæresten, den væltede Bæresten atter rejst, Kammelets Indre halvt fyldt med mindre Sten og Dixkstenen atter lagt paa Plads; den indtager nu en mindre faretruende skraa Stilling, end for dell ustlige Bæresten blev rejst. Alt ialt gor dette, af klumperle Sten byggede Dysisekammer et ejendoinmeligt Indtryk, som let ligger der nede $\mathrm{i}$ sin dybe Neilgravning.

(ira v 6 er ajensynlig Resterne af en Grav, lignente 3; en af sidstenenc, en trnol, kløvet Stenplade, er encluu paa Piads. Her i fancless j smaa Lerkar'skaar, prydet med parallele striber, dels som korte Streger unler Mundingsranden, ilels som striber paa Bugen, Paa Mar'ken nær denne

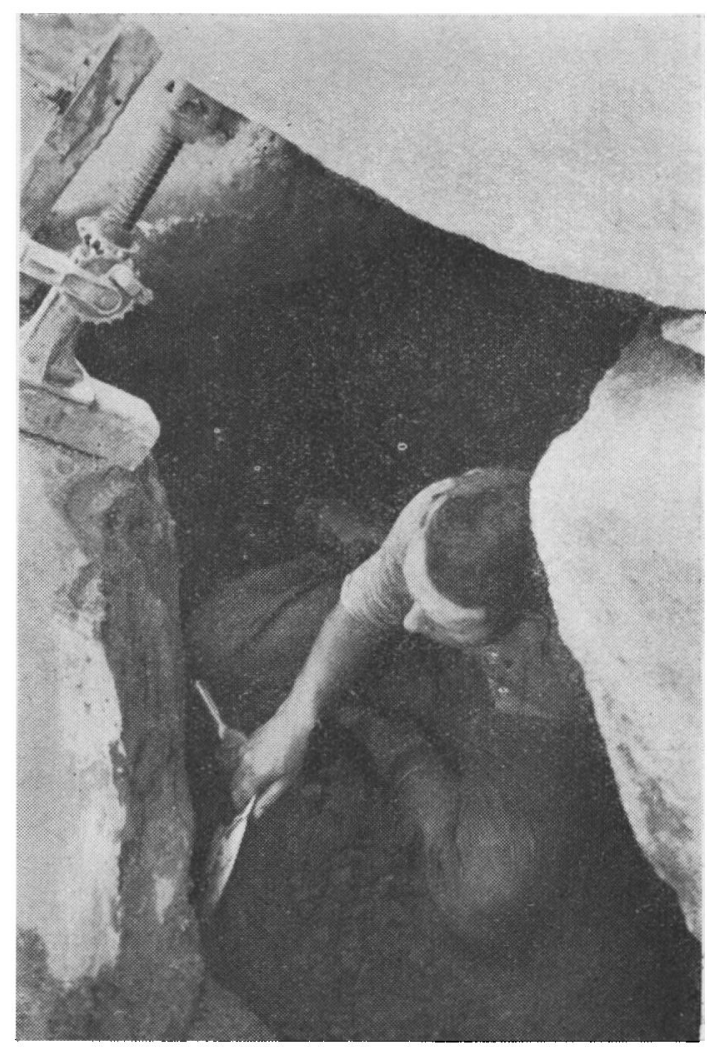

IFig. 8. Kammer 5 under Udgravnıng. Th. Andiesen fot.

Grav har Forpag-

torens Søn, Ebbe Poulsen, fundet en sleben, firsidet Flintmejsel (Fig. 10, 9), som han sksnkede til Nationalmuseet.

Foruden disse 6 Grave, der endnu kunde erkendes som Grave, selv om flere af dem var helt odelagte, fandtes der on- 
kring paa Pladsen en Del Stendysser og Stenlagninger, hvis Hensigt ikke altid var klar. Nogle af dem er utvivlsomt, som Fund af Oldsager viser, ødelagte Grave; andre er antagelig IYydningsbunker, der er gravet ned i Jorden. Stedet her er jo sneget rigt paa Sten, og særlig her paa Gravpladsen er Ploven ustandselig stødt paa Sten; antagelig har man da sanılet disse

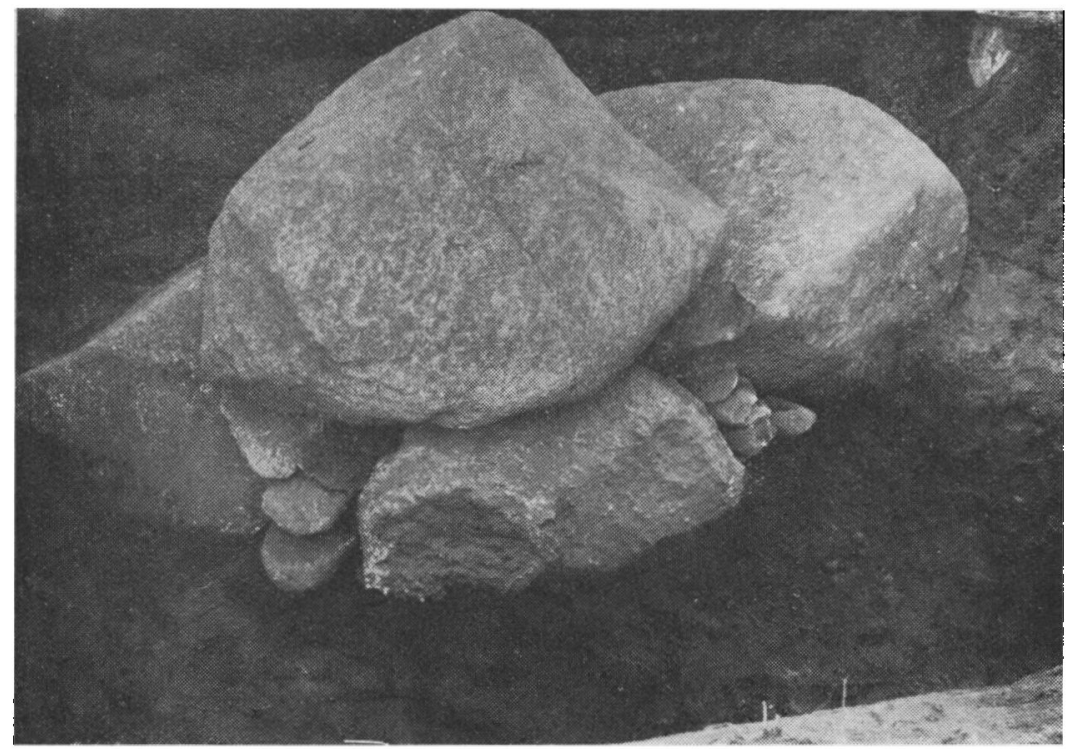

Fig. 9. Kammer 5 efter Restaureringen, set fra $\emptyset$ st.

T. M. fot.

ng gravet dem ned i Jorden. Det samme er antagelig Forklaringen paa den $18 \mathrm{~m}$ lange Stenrække, der strokker sig noget skraat herimellem Gravene og danner Fortsattelsen af de nordlige Sidesten i Grav 4; men disse Sten ligger langt dybere, i blandet Jord, og er af meget forskellig Storrelse. Det kunde taenkes, at der for at faa Stenene bort var gravet en Groft, hvori de var væltet ned; at der virkelig her har fundet senere Forstyrrelser Sted ses af, at dybt nede i demne blandede Jord fandtes et Jernalder Lerkarskaar.

Stenlægningerne 4 og 5 var lagt af ret smaa Sten, ret uregelmæssige og hullede; under dem laa et ca. $10 \mathrm{~cm}$ tykt blandet 

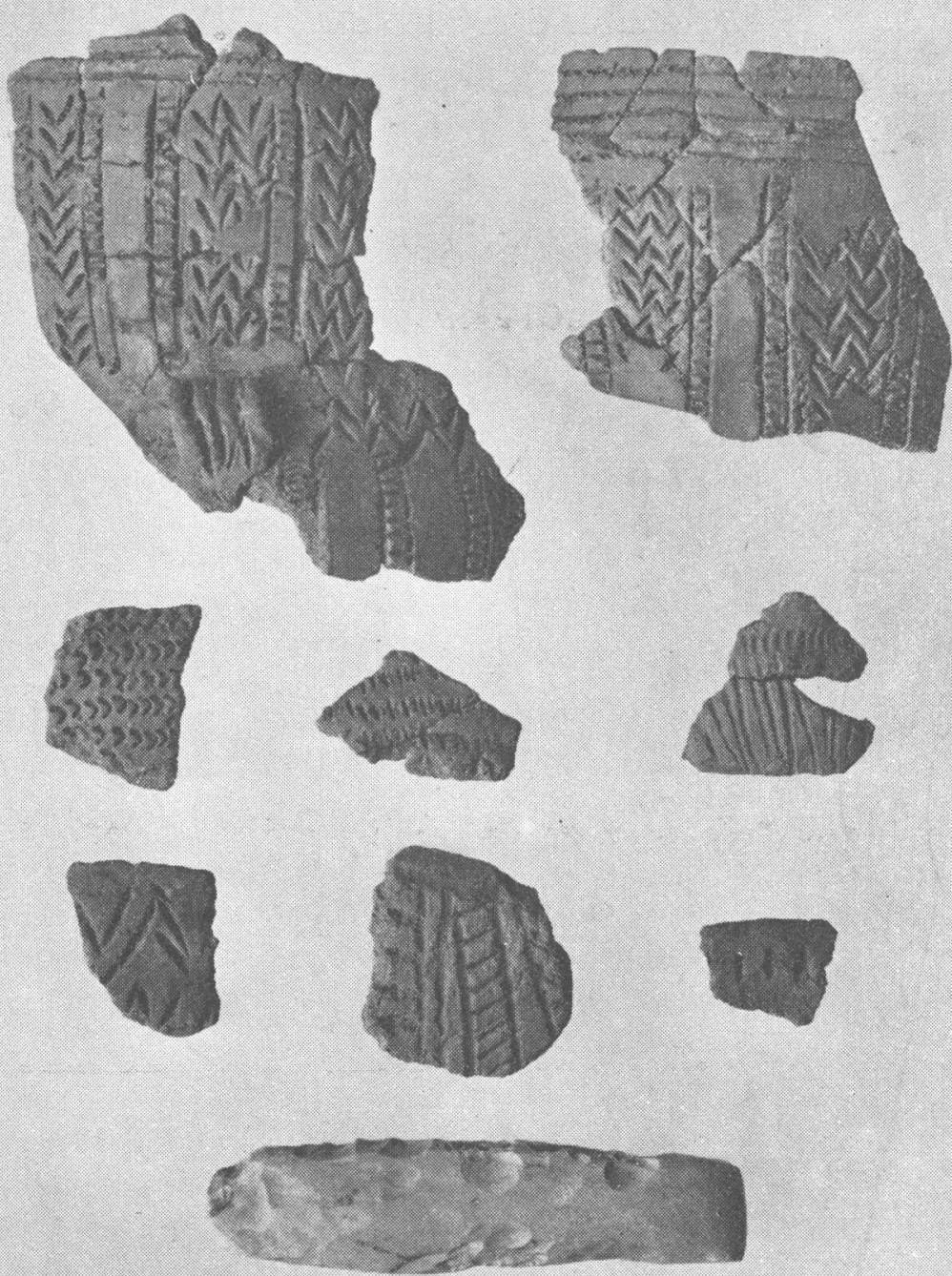

Fig. 10. Oldsager fra Harreby-Gravpladsen. $1: 2$.

1-2 og 4-7 er fra Stendynge 3, 3 fra Grav 3, 8 fundet i Fyldjord udenfor Graven og 9 fra nær Grav 6. 
Sandlag og herunder Undergrundens Grus. Lige Nord for 5 var der en Baalplads, ca. $2,0 \mathrm{~m}$ lang, $1,3 \mathrm{~m}$ bred, bestaaende af et tyndt Lag Trækul og Aske, der hvilte paa L'ndergrunden; j Vestenden af demne Baalplads var der et regulært Ildsted, en Grube, en halv Meter i Tværmaal, $0,40 \mathrm{~m}$ dyb, fyldt med ildskornede Sten, Trækul og sort Jord.

Ved flere af Stendyngerne er der som sagt gjort Fund af I.erkarskaar. I Stendynge 3 er der fundet $\$ 7$ Skaar, hørende til i hvert Fald 6 forskellige Kar, hvoraf nogle ses Fig. 10. 8 skaar l.orer til et Kar, hvoraf to store Flager ses 1-2; det er et rigt lekoreret Kar med rund Bug og omtrent lodret, vid Hals, med Hanke ved Overgangen mellem Bug og Hals. Ornamenterne. der hovedsagelig er orduet i lodrette Felter, er dybtskaarne og Jestaar hovedsagelig af striber paa langs og tvars og Vinkler": pa Hanken er der Furestik. 17 Skaar er af et har med lille, starkt livalvet, lodret afstribet Bug (j); tre andre skaar SES 4 (i.

Fra Stenlynge (i stammer li2 skaar af i hvert Fald to Kar, legge uomamenterede; det ene synes at have varet et tragtformet Kar med lille Standflade, det andet et ret stort Kar mul et Knark outrent midt paa siden. Sprealt i Fylden omkriug paa (iravpladsen er desuden fundet 4 smaa Skaar, dels merl Pindstik under Randen, dels af Tragtbagre med lodret afstribet Bug; desuden fandtes i Fyldjorden ved Stenrække 13 et Inxsten helt lille Lel kar med flad Standflade, rund Bug og lidt ulsvajet Mundingsrand, helt uden Ornamenter; det er 13 cm i 'værmaal over Bugen og $11.5 \mathrm{~cm}$ højt. (Fig. 11).

Hvad er nu det, der gor demne Gravplads ved Harreby saa markelig? Vi vil se lislt paa Kulturforholdene $i$ denne Del af Landet i den Tid, vi har med at gøre. Hvor i Tiden, vi befinder os, er nemlig gennem de fundne Oldsager, Flintmejslen og de rigt dekorerede Lerkar, klart nok: Det er den Del af Yingre Stenalder, vi kalder Eldre Jattestuetid, de sidste Aarhundreder af clet tredie Aartusinde for Kristi Fodsel. Dette Afsnit beteg- 
ner i flere Henseender Hojdepunktet af vor Stenalder-Bondekultur. Man dyrkede Jorden, Hvede og Byg, og holdt Husdyr, Koer, Svin og Faar, man boede i aflangt-firkantede, lerklinede Huse, der laa sammen i Landsbyer, som 'Troldebjerg-Landsbyen paa Langeland viser; man var dygtige Haandvarkere, kunde slibe Flinten og forfardige de smukke, slebne Flintokser, og navulig var man dygtige Pottemagere og frembragte de smukkeste og rigt dekorerede. Lerkar, der kendes fra vor Stenalder. De Døde begravede man i Jæettestuer, de store Kamre med Gang, der kunde rumme en Mrngde Begravelser, som man $i$ Sonderjylland kender det fra Over Jerstal og Vedsted; dog og-

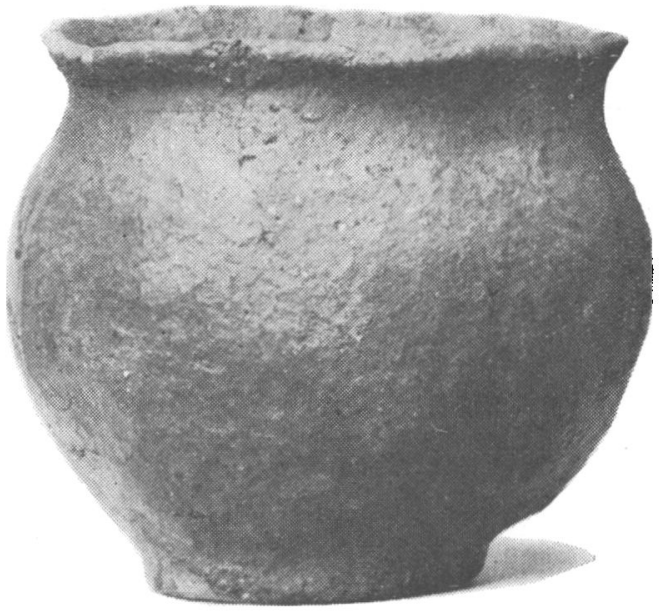

Fig. 11. Lerkar fra Dolktid, fundet i Fyldjord nær Stenrækken 13.

saa Dysser byggedes endinu, men i saa Fald de storre, oftest 5(i kantede Kamre, med een stor Overligger; ogsaa disse store Iyssekamre kunde rumme flere Begravelser. Baade Jættestuer og Dysser omgives af Høje; Jættestuerne var helt skjult deri, saa kun Gangens Aabning saas; derinod ragede Dyssens mægtige Daksten altid frem over Jorden, og saa var Højen i Reglen omkranset af oprejste Randsten.

Men netop i denne Periode indvandyer der et nyt Folk til l.andet; sydfra vandrer det op igennem Jylland og bosatter sig i de hidtil tỵndt befolkede Egne i Midt- og Vestịlland. Det er Enkeltgravsfolket, ogsaa et Bonde- og Hyrdefolk, men med helt andre Former af Redskaber og Vaaben og med en hel anden Gravskik: Enkeltgraven, anlagt uden Brug af store Sten, kun med en Ramme af mindre Sten, i Bunden af en lille Horj; 
Stridsøkser af elegante Former er det almindeligste Gravudstyr.

Naar vi nu betragter Harreby-Gravpladsen, er det for det forste paafaldende, at det er en Gravplads, der ligger under flad Mark og med flere Grave sammen; baade Jætterstuefolket: og Enkeltgravsfolkets Grave plejer som sagt at ligge i Høje, og i Reglen ligger de enkeltvis; hvor der ligger flere sammen, el det oftest i en Langdysse, hvori $2-3$ Kamre ligger paa Række; men aldrig træffer man dem som her, hvor Gravene ligger mellem hinanden uden nogen Plan, vendende forskellig Vej. Dernæst træffer vi her aflangt-firkantede Dyssekamre, der øjensynligt er bygget saa sent som i Jattestuetid,') medens denne Gravtype ellers hører hjemme i Dyssetid, Yngre Stenaluers første Afsnit. Og disse Dysser er gravet ned i Jorden, saa der ligger ct godt Lag Jord op over Dækstenen, dog ikke i Høj, men under fiad Mark.

Nedgravede Dyssekamre kendes ogsaa andetsteds fra ${ }^{2}$ ); og netop i Haderslev Amt synes de at være forholdsvis talrige ogat stamme hovedsagelig fra Jiettestuetid; men disse ligger enkeltvis og synes i de fleste Tilfælde at have været omgivet af en Høj; det er altsaa alligevel noget andet end ved Harreby.

Men ved Harreby forekommer der ogsaa ved Siden af Dysserue en anden Slags Grave, Enkeltgrave, omgivet af en Stenramme, i nogle Tilfælde (som ved Grav 3) ganske vist en ret svær, kistelignende Ramme; men dog alligevel en Gravtype. der staar Enkeltgravene nærmere end Stengravene. Andre Girave, 4 og 6, synes at have en endnu spinklere Stenramme. men var iøvrigt for ødelagte til, at noget sikkert kan siges herom. Der er saaledes utvivlsomt Enkeltgrave ved Harreby, men disse afviger fra de sædvanlige, dels ved at ligge flere sammen under flad Mark, dels ved at være orienteret i flere forskellige Ret-

1) Noget lignende synes iovrigt at have varet Tilfaldet i Brandshol Skov paa Als, se Therkel Mathiassen: Bundso, en Yngre Stenalders Boplads paa Als. Aarboger for nordisk Oldkyndighed 1939 , S. $45-55$.

2) Se Neumann i Fra Danmarks Cngtid. 
ninger, medens de sædvanlige Enkeltgrave altid ligger i OstVest.

Harreby-Gravpladsen viser saaledes en mixrkelig Blanding af Træk, kendt baade fra Stengravs- og Eukeltgravs-Kulturen, samt noget helt nyt og for denne Tid usædvanligt: Flere Grave sammen under flad Mark. Tidell, da Gravpladsen er anlagt, er -Eldre Jættestuetid; men et Par Fund tyder paa, at Pladsen endnu har været benyttet henimod Stenalderens Slutning, i Dolktiden: I Grav 1 er fundet et Brudstykke af en Flintdolk (eller spydspids), og Karret Fig. 10 horer ogsaa hjemme i denne Tid.

Er det da Stengravs- eller Enkeltgravsfolk, der har bvgget Ilarreby-Gravpladsen? Vi befinder os i en Egn, hvor der i Modsatning til de fleste andre vest- og midtjydske Fgne or nogle Stengrave, ogsaa fra ældre Jxttestuetid ${ }^{1}$ ); men invrigt er det Finkeltgravskulturen, der dominerer i dette strog. Antagelig er let en Gruppe Stengravsfolk, der har boet her; det ser man af de efterladte Oldsager, Mejslen, Keramik; der er ikke et eneste Stykke, der tyder paa Enkeltgravskultur. Men i Gravskikken ser vi ell stærk Paavirkning fra Enkeltgravskulturen. Hvad vil dette egentlig sige? Formodentlig at disse har antaget de omboende Enkeltgravsfolks Religion; Gravskikken maa jo skyldes de Forestillinger, man gor sig om et Liv efter Døden, altsaa Religionen. Men denne nye Religion har de ikke helt optaget og forstaaet; flere af deres gamle Forestillinger har de bevaret, og Resultatet er da blevet denne mærkelige Blanding af forskellige Gravskikke, smaa Dysser, der antagelig er Enkeltgrave, omsat rred store Sten, som det var Stengravsfolkets Skik, og rigtige Enkeltgrave, kun med en Stenramme, men begge Former i forskellig Orientering; og som et yderligere Udslag af deres aandelige Forvirring er da Gravene blevet lagt i en Gruppe under flad Mark. ${ }^{1}$ )

1) Se Kortet i Brondsted, Danmarks Ohdid, I, S. 210.

1) Noget i samme Retning, Enkeltgrave, bygget som smaa, spinkle Stenkister og med Stengravs-Oldsager fra Jattestuetid, kendes fra Gravene ved Zeijen og Diever i Provinsen Groningen, Holland; men disse ligger enkeltvis og under Hoje. (A. E. van Giffen: Lie Bauart der F.inzelgräber: Mannus-Bibliotlıek Nr, 44, Leipzig 19:30, S. 10-26). 
Saaledes yder Harreby-Gravpladsen sit lille Bidrag til Forstaaelsen af Forholdet mellem Stengravsfolk og Enkeltgravsfolk, a to Folk, ved hvis Sammensmeltning det Folk blev skabt, som endnu bebor og dỵker den danske Jord. 